\title{
Investigating transport capacity equations in sediment yield modelling for the Cariri semi-arid region of Paraiba-PB/Brazil
}

\author{
EDUARDO E. DE FIGUEIREDO ${ }^{1}$, CAIO CÉSAR R. A. SOUTO ${ }^{1} \&$ \\ ZACARIAS CAETANO VIEIRA ${ }^{2}$ \\ 1 Federal University of Campina Grande/Brazil, PO Box 505, Campina Grande/PB, Brazil \\ eneasef@yahoo.com \\ 2 Federal Institute of Sergipe, Av Eng Gentil T. da Mota 49055-260 Aracajú/SE, Brazil
}

\begin{abstract}
In the semi arid Cariri region of the state of Paraiba, Brazil, runoff is of the Hortonian type generated by excess of rainfall over infiltration capacity, and soil erosion is governed by rainfall intensity and sediment size. However, the governing sediment transport mechanism is not well understood. Sediment transport generally depends on the load of sediment provided by soil erosion and on the transport capacity of the flow. The latter is mainly governed by mechanisms such as water shear stress, or stream power. Accordingly, the load of sediment transported by the flow may vary depending on the mechanism involved in the equation of estimation. Investigation of the sediment transport capacity of the flow via a distributed physically-based model is an important and necessary task, but quite rare in semi-arid climates, and particularly in the Cariri region of the state of Paraíba/Brazil. In this study, the equations of Yalin, Engelund $\&$ Hansen, Laursen, DuBoys and Bagnold have been coupled with the MOSEE distributed physically based model aiming at identifying the mechanisms leading to the best model simulations when compared with data observed at various basin scales and land uses in the study region. The results obtained with the investigated methods were quite similar and satisfactory suggesting the feasibility of the mechanisms involved, but the observed values were better represented with Bagnold's equation, which is physically grounded on the stream power, and we recommend it for simulations of similar climate, runoff generation mechanisms and sediment characteristics as in the study region.
\end{abstract}

Key words flow transport capacity, physically-based model; semi-arid region

\section{INTRODUCTION}

Runoff, soil erosion, and sediment transport are complex processes to model in semi-arid regions owing to the variability of the governing factors (e.g. rainfall, soil, relief, vegetation). While runoff and soil erosion are processes governed by the rainfall intensity, slope and land use, sediment transport depends on the sediment provided by soil erosion and on the transport capacity by the flow. Moreover, sediment transport estimations may vary depending on the method of flow transport capacity utilized. Several sediment transport capacity equations have been reported in the literature (see Julien \& Simons, 1985) and utilized together with runoff-erosion-transport models (e.g. SHETRAN, Ewen \& Parkin, 2000). However, their suitability in representing the process in specific climates (e.g. semi-arid regions where rainfall is generally of high intensity, runoff and soils are shallow and vegetation is scarce) needs investigation. In this study, the flow transport capacity equations of Duboys (1879), Laursen (1958), Yalin (1963), Bagnold (1966) and Engelund \& Hansen (1967), which are based on mechanisms such as excess of water shear stress over critical sediment shear and stream power, have been coupled with the MOSEE distributed physically-based model (Figueiredo \& Parsons, 2010). The model was used with data observed at various catchment scales and land uses in the semi-arid Cariri region of the state of Paraiba/Brazil (Vieira, 2011; Souto, 2013), aiming at testing the model's capability to simulate runoff, soil erosion and transport, and identifying the mechanism leading to best fit model simulations when compared with data observed in the region. The investigation is described herein.

\section{SEDIMENT TRANSPORT MECHANISMS}

Sediment transport depends on the transport capacity of the flow, and it is thought to follow two conditions: (1) if the total load of sediment provided exceeds the transport capacity then the sediment transported equals the transport capacity, and the difference is deposited; (2) if the transport capacity exceeds the total load of sediment provided then the transport of sediment equals the total load of sediment provided, and in this case there is no deposition.

Two mechanisms are predominant in most transport capacity equations: (1) excess of flow shear; (2) stream power. The former considers that the transport of sediment occurs when the flow 
shear stress $(\tau)$ is greater than the shear that the sediment can withstand, the critical shear stress $\left(\tau_{\mathrm{c}}\right)$. That is, $\tau>\tau_{\mathrm{c}}\left(\mathrm{kgf} \mathrm{m}^{-2}\right)$, with $\tau=\rho \mathrm{gd}_{\mathrm{w}} \mathrm{S}$, where $\rho$ is the water density $\left(1000 \mathrm{~kg} \mathrm{~m}^{-3}\right), \mathrm{g}$ is gravity $\left(9,806 \mathrm{~m} \mathrm{~s}^{-2}\right), \mathrm{d}_{\mathrm{w}}$ is flow depth $(\mathrm{m}), \mathrm{S}$ is slope $(-)$, and $\tau_{\mathrm{c}}$ is the critical shear $\left(\mathrm{kgf} \mathrm{m}^{-2}\right)$ given in terms of the sediment diameter $D_{s}(m)$, that is $\tau_{c}=\tau_{c}\left(D_{s}\right)$. The latter is based on the principle that the available energy of the flow ( $\tau \mathrm{Q}$, where $\mathrm{Q}$ is the flow discharge) is the energy source to transport the bed and suspended sediment (Bagnold, 1966). The stream power mechanism is established based on the concept of efficiency $(\eta)$, which is the ratio of the energy required $\left(e_{r}\right)$ for the transport of sediments (bed and suspended) to the available energy of the flow $\left(\mathrm{e}_{\mathrm{q}}\right)$. That is $\eta=$ $\mathrm{e}_{\mathrm{r}} / \mathrm{e}_{\mathrm{q}}$ or $\eta=\left(\mathrm{e}_{\mathrm{b}}+\mathrm{e}_{\mathrm{s}}\right) / \mathrm{e}_{\mathrm{q}}=\eta_{\mathrm{b}}+\eta_{\mathrm{s}}$, where $\mathrm{e}_{\mathrm{b}}$ and $\mathrm{e}_{\mathrm{s}}$ are the energy for the transport of bed and suspended sediments, and $\eta_{\mathrm{b}}$ and $\eta_{\mathrm{s}}$ the bed and suspended efficiencies. The energy is the working rate $\left(\mathrm{kgf} \mathrm{m} \mathrm{s}^{-1}\right)$, required $\left(\mathrm{e}_{\mathrm{r}}, \mathrm{e}_{\mathrm{b}}, \mathrm{e}_{\mathrm{s}}\right)$ or available $\left(\mathrm{e}_{\mathrm{q}}\right)$, which can also be expressed as the energy per flow width $\mathrm{C}_{\mathrm{w}}\left(\mathrm{kgf} \mathrm{s}^{-1}\right)$. Bagnold (1966) showed that $\eta_{\mathrm{b}}=\operatorname{tg}(\alpha) \mathrm{e}_{\mathrm{b}} / \mathrm{e}_{\mathrm{q}}$ and $\eta_{\mathrm{s}}=\mathrm{e}_{\mathrm{s}}\left[\left(1-\eta_{\mathrm{b}}\right) \mathrm{e}_{\mathrm{q}}^{-1}\right] \mathrm{U}_{\mathrm{s}} \mathrm{W}_{\mathrm{f}}^{-1}$, where $\operatorname{tg}(\alpha)$ is the ratio of the tangential force $(\mathrm{T})$ (to the plane of shear in the flow direction) to the normal force $(\mathrm{P}), \alpha$ the angle between $\mathrm{T}$ and $\mathrm{P}$ (or the angle of repose of the sediment), $\left(1-\eta_{\mathrm{b}}\right) \mathrm{e}_{\mathrm{q}}$ is the net available energy for the suspended sediment, and $\left(\mathrm{U}_{\mathrm{s}} \mathrm{W}_{\mathrm{f}}^{-1}\right)$ the ratio of the mean transport velocity of solids $\left(\mathrm{U}_{\mathrm{s}}\right)$ to the sediment fall velocity $\left(\mathrm{W}_{\mathrm{f}}\right)$. The available energy of the flow is $\mathrm{e}_{\mathrm{q}}=$ $\tau \mathrm{Q}$ or $\mathrm{e}_{\mathrm{q}}=\rho \mathrm{gd}_{\mathrm{w}} \mathrm{SQ}$. The total energy required to transport the immersed sediment is $\mathrm{e}_{\mathrm{r}}=\left(\mathrm{e}_{\mathrm{b}}+\right.$ $\left.e_{s}\right) \rho /\left(\rho_{s}-\rho\right)$, where $\rho_{s}$ is the density of the sediment.

\section{TRANSPORT CAPACITY EQUATIONS}

To study the suitability of the mechanisms previously described to represent the sediment transport process in the Cariri semi-arid region of the state of Paraiba, Brazil, the following flow transport capacity equations were chosen and coupled with the MOSEE model (Figueiredo \& Parsons, 2010): DuBoys (1879) for bedload, Laursen (1958) for total load, Yalin (1963) for bedload, Bagnold (1966), which counts up the total load as the sum of suspended and bedloads, and Engelund \& Hansen (1967) for total load.

The equations of DuBoys (eq. 1) and Yalin (eq. 2) are based on the excess of shear. The equations of Laursen (eq. 3) and Engelund \& Hansen (eq. 4) mix the mechanisms of stream power and excess of shear. Bagnold's equation (eq. 5) is based on the stream power of the flow, which can be used to determine the bed and suspended load separately. The equation of Laursen is for quartz sand and accounts for the percentage $\left(\mathrm{P}_{\mathrm{i}}\right)$ of particle size $\left(\mathrm{D}_{\mathrm{si}}\right)$ distribution (for just one representative diameter $P_{i}=100$ and $D_{s i}$ is the median diameter $D_{50}$, which is utilized in the other methods).

$\begin{array}{ll}\text { DuBoys (1879) } & D B_{b}=\mathrm{C}_{\mathrm{w}} \Psi_{\mathrm{D}} \tau\left(\tau-\tau_{\mathrm{c}}\right) \\ \text { Yalin (1963) } & Y A_{b}=0.635 C_{w} \gamma_{\mathrm{S}} \sqrt{\frac{\tau}{\rho}} D_{s}\left(\frac{\tau}{\tau_{c}}-1\right)\left[1-\frac{\ln (1+\beta)}{\beta}\right] \\ \text { Laursen (1958) } & L A_{t}=\frac{1}{100} \gamma Q \sum_{i} P_{i}\left(\frac{D_{s i}}{d_{w}}\right)^{\frac{7}{6}}\left(\frac{\tau}{\tau_{c}}-1\right) f\left(\frac{U_{*}}{W_{i}}\right) \\ \text { E. \& Hansen (1967) } & E H_{t}=0.05 C_{w} \gamma_{\mathrm{S}} \mathrm{U}^{2}\left[\frac{\mathrm{D}_{\mathrm{s}}}{\mathrm{g}\left(\frac{\gamma \mathrm{s}}{\gamma}-1\right)}\right]^{\frac{1}{2}}\left[\frac{\tau}{(\gamma \mathrm{s}-\gamma) \mathrm{D}_{\mathrm{s}}}\right]^{3 / 2} \\ \text { Bagnold (1966) } & B A_{t}=C_{w}\left(\frac{\rho}{\rho_{s}-\rho}\right) \tau Q\left(\frac{\eta_{b}}{\tan \alpha}+\eta_{s}\left(1-\eta_{b}\right) \frac{U}{w}\right)\end{array}$

Equations (1) to (5) give transport capacity in weight per unit time $\left(\mathrm{kgf} \mathrm{s}^{-1}\right)$. Subscripts $b$ and $t$ are for bed and total load. Parameters and/or terms in the equations are defined as follows:

- DuBoys' parameters (eq. 1): $\Psi_{\mathrm{D}}=\gamma_{\mathrm{s}} \chi\left(\mathrm{m}^{3} \mathrm{kgf}^{-1} \mathrm{~s}^{-1}\right)$ is related to the sediment characteristics, where $\gamma_{\mathrm{s}}$ is the specific weight of the sediment $\left(\mathrm{kgf} \mathrm{m}^{-3}\right)$, and $\chi$ is a sediment characteristic coefficient $\left(\mathrm{m}^{6} \mathrm{kgf}^{-2} \mathrm{~s}^{-1}\right)$.

- Yalin's parameters (eq. 2): $\beta=2.45\left(\rho_{\mathrm{s}} / \rho\right)^{-0.4}\left(\tau / \tau_{\mathrm{c}}-1\right) \tau_{\mathrm{c}}{ }^{0.5}$, and $\tau_{\mathrm{c}}$ is Shields' critical shear. 
- Laursen's parameters (eq. 3): $\mathrm{f}\left(\mathrm{U}_{*} / \mathrm{w}_{\mathrm{i}}\right)$ is a dimensionless shear function related to the ratio of shear velocity $\left(\mathrm{U}_{*}=\sqrt{g D_{S} S}\right)$ and fall velocity $\left(\mathrm{W}_{\mathrm{fi}}\right)$ of the particle size diameter $\mathrm{D}_{\mathrm{si}}$.

- Engelund \& Hansen's equation (eq. 4) is a straightforward method having no particular parameters to be determined.

- Bagnold's parameters (eq. 5): $\eta_{\mathrm{b}}$ is the bed load efficiency given in terms of the mean flow velocity $U$ and grain size $D_{s}, \operatorname{tg}(\alpha)$ ( $\alpha$ is the angle of repose of the sediment) is given in terms of the dimensionless bed shear stress $\tau /\left(\rho_{s}-\rho\right) g D_{s}$, and $\eta_{s}\left(1-\eta_{b}\right)=0.01$ (Bagnold, 1966).

\section{THE MOSEE MODEL}

MOSEE stands for MOdel for Soil Erosion Estimation (Figueiredo \& Parsons, 2010). It is an enhanced version of MOSESS_D (Figueiredo, 2008), which is the distributed version of the smallscale model MOSESS (Figueiredo \& Davi, 2006). Figueiredo \& Davi (2006) applied MOSESS for plots $\left(100 \mathrm{~m}^{2}\right)$ and micro-basins (up to 1 hectare) of the experimental basin of Sumé (EBS), in the representative basin of Sumé (RBS), and obtained reasonable results. Figueiredo (2008) simulated runoff and soil erosion with MOSESS_D for comparisons with simulations by Lopes (2003), with KINEROS2 (Woolhiser et al., 1990) and WESP (Lopes, 2003), and by Figueiredo \& Bathurst $(2005,2006)$ with SHETRAN (Ewen \& Parkin, 2000), and concluded that runoff compared well but the sediment yields (based on Engelund \& Hansen, 1967) were relatively poor, and suggested further investigation on other methods of sediment transport capacity.

The characteristics of the model are as follows. The basin system is divided into subcatchments, which are linked to each other by a channel reach. Soils, relief, land use, and processes of the water cycle (rainfall, interception, evapotranspiration, infiltration and runoff) are calculated for each area. Three soil horizons are assigned, the surface layer where rainwater (rainfall intensity is space-variant) infiltrates, and two subsurface layers underneath where the infiltrated water increases the layers' moisture. Interception is represented by the depth of rainfall intercepted by canopy, which can be attributed according to the type of vegetation. Actual evapotranspiration rates are based on the ratio of actual to potential evapotranspiration and soil tension. Infiltration depends on the surface infiltration capacity estimated with a potential equation or a function of the Horton type. Percolation in the unsaturated zone is determined according to the lowest non-saturated hydraulic conductivity of the two adjacent layers. Non-saturated and saturated hydraulic conductivities vary with sand and clay percentages in the soil profile. Surface runoff is generated either when the surface soil layer saturates, rainfall intensity exceeds infiltration capacity, or when these conditions happen simultaneously. Subsurface and groundwater flows are based on Darcy's law, with the water elevation in the river interacting with the water level in the bank soil. Channel flow is routed to downstream reaches using the convex procedure in McCuen (1982), with the wave translation time according to Kirpich (1940). Soil erosion is due to rainfall and runoff (the loads are added to count up the total load provided for transport), and sediment transport dependent on the transport capacity of the flow. Erosion by rainfall is based on the squared moment for rainfall, and by runoff on Shields' critical shear stress. The effect of flow depth and ground cover in reducing raindrop impact is considered. The equations and parameters in the model are not presented herein; for details see Figueiredo \& Parsons, 2010.

\section{RUNOFF, SOIL EROSION AND SEDIMENT TRANSPORT MODELLING}

The simulations carried out by Vieira (2011) and Souto (2013) are the basis for the current investigation. Their simulations were based on data from a rainfall network with recorded data of precipitation covering dry, normal and wet years, and data of runoff observed at the outlets of nested catchments (plots and micro-basins of the EBS and EBSJC, and sub-basins of the RBS and EBSJC) in the Cariri semi-arid region of the state of Paraíba (Fig. 1), Northeast of Brazil. For the aim of this study, only the simulations at the micro-basins M1 to M3 in the EBS (with data from 1984 to 1986) and M1 to M3 in the EBSJC (with data from 2002 to 2004) were utilized. 


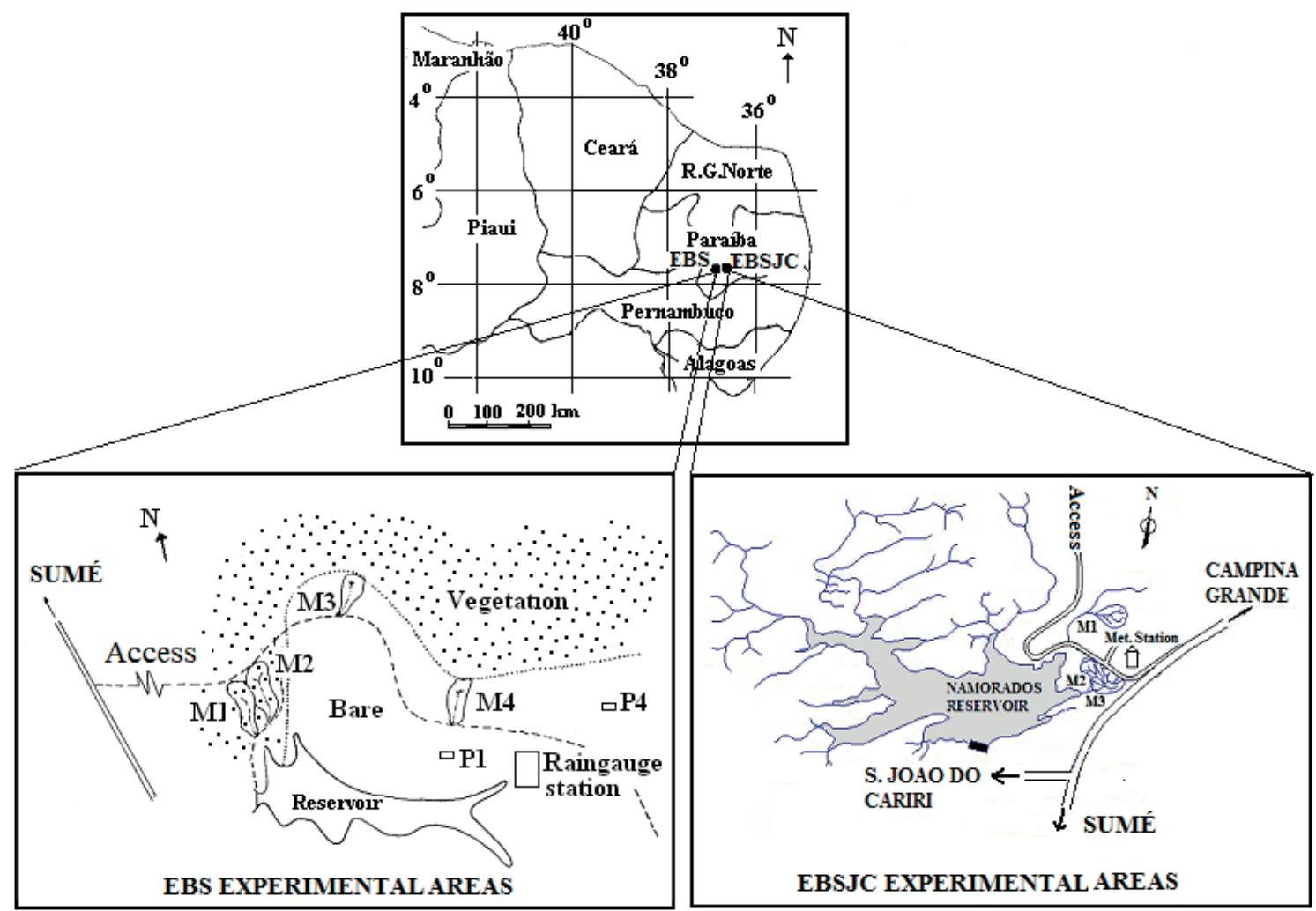

Fig. 1 EBS and EBSJC experimental areas of Sumé and São João do Cariri (adapted from Figueiredo \& Bathurst, 2006; and FINEP, 2004).

All micro-basins were divided into 20 sub-catchments of contribution, with their characteristics fixed based on field observations (soil, slope, reach, cover). Parameters related to soils, relief, reaches, texture, and methodologies utilized for the calculations of precipitation, interception, actual evapotranspiration, and hydraulic conductivities are described elsewhere (see Figueiredo, 2008; Figueiredo \& Parsons, 2010; Vieira, 2011; Souto, 2013). The parameter values are summarized in Tables 1a (adapted from Figueiredo \& Bathurst, 2005), 1b and 1c (adapted from Vieira, 2011; and Souto, 2013).

Runoff modelling consisted in calibrating by trial and error the coefficient of propagation $\mathrm{C}=$ $\Delta t / t_{c}$ of the SCS flood routing procedure (McCuen, 1982), where $\Delta t$ is the time interval and $t_{c}$ is Kirpich's (1940) time of concentration of the reach $\left(\Delta t \leq t_{c}\right)$, in order to match simulated annual peaks and volumes close to observed figures. Values of $\mathrm{C}$ varied from 0.498 to 0.998 (EBS microbasins) and from 0.172 to 0.999 (EBSJC micro-basins).

Soil erosions by rainfall and runoff are controlled in the model by two coefficients: the rainfall and runoff erosivity coefficients $\left(\mathrm{k}_{\mathrm{r}}\right.$ and $\left.\mathrm{k}_{\mathrm{f}}\right)$. Calibration of $\mathrm{k}_{\mathrm{r}}$ was carried out by trial and error so as to get observed sediment yields and peaks well represented by the simulations. Erosion by runoff was neglected since even very small values set to $\mathrm{k}_{\mathrm{f}}$ generated huge unrealistic loads of sediment. In addition, runoff is very shallow in the areas investigated. Values of $\mathrm{k}_{\mathrm{r}}$ for annual sediment yields (peaks are not presented herein) varied from 0.0033 to 15.75 (EBS micro-basins), and from 0.008 to 0.415 (EBSJC micro-basins).

Sediment transport modelling consisted in fixing parameters inherent to the investigated methods as follows:

- Sediment characteristics were obtained from sieve analyses of the eroded sediment (Table 1c), which allowed fixing $\mathrm{D}_{50}$ ( 0.4 for the EBS micro-basins and 0.3 for the EBSJC micro-basins).

- DuBoys' parameters (eq. 1) $\gamma_{\mathrm{s}} \chi$ and $\tau_{\mathrm{c}}$, which are available in Graf (1971), page 127, for diameters $0.1 \mathrm{~mm}<\mathrm{D}_{\mathrm{s}}<4.0 \mathrm{~mm}$, were digitized and equations $\left(\gamma_{\mathrm{s}} \chi=1.7998\left(1000 \mathrm{D}_{\mathrm{s}}\right)^{-0.731} ; \tau_{\mathrm{c}}\left(\mathrm{kgf} \mathrm{m}^{-2}\right)=\right.$ $0.0942\left(10^{3} \mathrm{D}_{\mathrm{s}}\right)+0.062$ with $\mathrm{D}_{\mathrm{s}}$ in $\left.\mathrm{mm}\right)$ were established by regression analysis $\left(\mathrm{R}^{2}>0.995\right)$. 
Table 1a Parameter values for the EBS and EBSJC micro-basins.

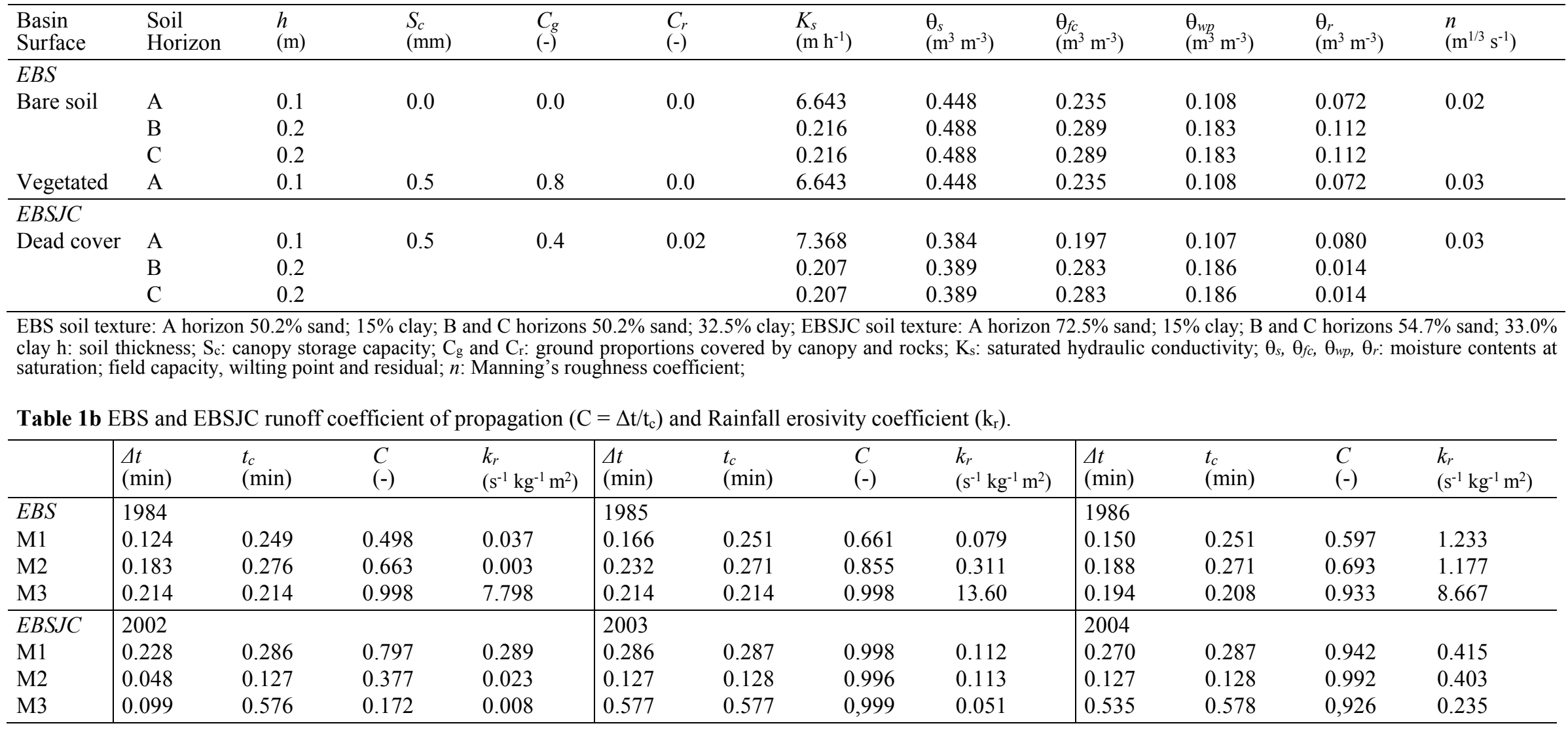


Table 1c Sieve analysis of eroded sediment in the EBS and EBSJC.

\begin{tabular}{|c|c|c|c|c|c|c|c|c|c|}
\hline$E B S$ & $\mathrm{D}_{1}$ & $\mathrm{D}_{2}$ & $\mathrm{D}_{3}$ & $\mathrm{D}_{4}$ & $\mathrm{D}_{5}$ & $\mathrm{D}_{6}$ & $\mathrm{D}_{7}$ & $\mathrm{D}_{8}$ & $\mathrm{D}_{9}$ \\
\hline $\mathrm{D}_{\mathrm{i}}(\mathrm{mm})$ & 0.1 & 0.2 & 0.3 & 0.4 & 0.7 & 1.0 & 2.0 & 6.0 & 10.0 \\
\hline$P_{i}(\%)$ & 10.0 & 25.0 & 35.0 & 50.0 & 70.0 & 80.0 & 90.0 & 98.0 & 99.5 \\
\hline \multicolumn{10}{|l|}{ EBSJC } \\
\hline $\mathrm{D}_{\mathrm{i}}(\mathrm{mm})$ & 0.1 & 0.15 & 0.25 & 0.3 & 0.4 & 0.85 & 2.0 & 4.0 & 5.0 \\
\hline $\mathrm{P}_{\mathrm{i}}(\%)$ & 1.0 & 8.00 & 45.0 & 50.0 & 60.0 & 85.0 & 95.0 & 98.0 & 99.5 \\
\hline
\end{tabular}

- Yalin's critical shear (eq. 2) was calculated by $\tau_{\mathrm{c}}=\left(\gamma_{\mathrm{s}}-\gamma\right) \cdot \mathrm{D}_{\mathrm{s}} \cdot a \cdot \mathrm{R}_{\mathrm{p}}{ }^{b}$, with the particle Reynolds number $\mathrm{R}_{\mathrm{p}}=\max \left[0.03, \mathrm{D}_{50}(\tau / \rho)^{0.5} / \mathrm{v}\right]$, and $a(0.056$ to 0.1$)$ and $b(-0.3$ to 0.0$)$ factors varying with $R_{p}(0.03$ to 400$)$.

- Laursen's parameter $\mathrm{f}\left(\mathrm{U}_{*} / \mathrm{W}_{\mathrm{i}}\right) \times \mathrm{U}_{*} / \mathrm{W}_{\mathrm{fi}}$ (eq. 3) is available in Vanoni (1975), page 203, for different intervals of the dimensionless shear velocity $\left(0.01<\mathrm{U}_{*} / \mathrm{W}_{\mathrm{fi}}<1000\right)$; data were digitized and equations (linear and non-linear) were adjusted by regression analysis, with the sediment fall velocity $\mathrm{W}_{\mathrm{fi}}$ calculated according to Rubin (for details see Vanoni, 1975).

- Bagnold's parameters (eq. 5) $\eta_{\mathrm{b}}$ (given in terms of the mean flow velocity $U$ and grain size $\mathrm{D}_{\mathrm{s}}$ varying from $0.03 \mathrm{~mm}$ to $1.0 \mathrm{~mm}$ ) and $\operatorname{tg}(\alpha)$ (given in terms of the dimensionless bed shear stress $\tau /\left[\left(\rho_{\mathrm{s}}-\rho\right) \mathrm{gD}_{\mathrm{s}}\right]$ and grain sizes in the range $\left.0.25<\mathrm{D}_{\mathrm{s}}<2 \mathrm{~mm}\right)$, available in Bagnold (1966), were digitized and equations were adjusted by regression $\left(\mathrm{R}^{2}>0.97\right)$ analysis, and $\eta_{\mathrm{s}}\left(1-\eta_{\mathrm{b}}\right)=0.01$.

\section{RESULTS AND DISCUSSION}

Comparisons of observed annual runoffs and sediment yields with simulated values are given in Table 2. Results for peaks are not presented herein because they are based on single pairs of values. Sediment simulations in Table 2 were all with the transport capacity equation of Engelund $\&$ Hansen (eq. 4). Table 2 shows percentage errors of estimation and the coefficient of determination (from a linear regression analysis), which are the criteria utilized to analyse the model's capability of representing runoff-erosion processes in the study region. In general, it can be seen that the percentage errors are small, but slightly smaller for sediment yields than runoffs (for the runoffs $\mid 0.1$ to $74 \% \mid$, and sediment yields $\mid 0.0$ to $13 \% \mid$ ). The simulated runoffs generally underestimated the observed figures in the EBSJC, but were significant for the micro-basins in the dry year of 2003. The coefficients of determinations are quite reasonable for the runoffs $\left(0.48<\mathrm{R}^{2}\right.$ $<0.98)$, and sediment yields $\left(0.14<\mathrm{R}^{2}<0.8\right)$. These results suggest that the observed annual runoffs and sediment yields are well represented by the model simulations and give a good ground for the investigation of sediment transport with the transport capacity equations coupled to MOSEE.

Table 3 shows errors in sediment transport simulations carried out with the other four transport capacity equations investigated, all of them with the same parameter values as previously fixed. It can be seen that the simulations based on the Laursen equation led to errors $(\mid 0.0$ to $73 \% \mid)$ greater than the ones with the other equations $(\mid 0.0$ to $29 \% \mid)$. It must be noted that the Laursen equation should be applied considering the sediment size distribution, but in doing so the results could not be compared with those from the other equations, which take $\mathrm{D}_{50}$ as the representative sediment diameter. For the other cases, it is seen that the percentage errors are quite similar when compared to each other. This is right because of the fact that in almost all cases soil erosion was less than transport capacity (in fact the transport capacities calculated with the equations vary from each other). Therefore, in a fine sense all the equations investigated are reasonable suggesting that the mechanisms of excess of flow shear and stream power go well with the process in the region. The simulations with Bagnold's equations are slightly more representative than those with the other methods because it is fully physically based, and accounts for suspended and bed loads. 
Table 2 Annual runoff (Q) and sediment yields (Sy) in the EBS and EBSJC micro-basins.

\begin{tabular}{|c|c|c|c|c|c|c|c|c|c|}
\hline $\begin{array}{l}\text { Basin } \\
\text { Year } \\
\text { P (mm) }\end{array}$ & $\begin{array}{l}\text { Site/Area } \\
\left(10^{-3} \mathrm{~km}^{2}\right)\end{array}$ & $\begin{array}{l}\text { Qo } \\
(\mathrm{mm})\end{array}$ & $\begin{array}{l}\text { Qs } \\
(\mathrm{mm})\end{array}$ & $\begin{array}{l}\text { Error } \\
(\%)\end{array}$ & $\mathrm{R}^{2}$ & $\begin{array}{l}\text { Syo } \\
\left(10^{-3} t\right)\end{array}$ & $\begin{array}{l}\mathrm{Sys}^{1} \\
\left(10^{-3} \mathrm{t}\right)\end{array}$ & $\begin{array}{l}\text { Error } \\
(\%)\end{array}$ & $\mathrm{R}^{2}$ \\
\hline \multirow{4}{*}{$\begin{array}{l}\text { EBS } \\
1984 \\
(546.8)\end{array}$} & $\mathrm{M} 1^{2} / 6.2$ & 5.14 & 5.09 & -0.97 & 0.909 & 3.8 & 3.9 & 2.63 & 0.668 \\
\hline & $\mathrm{M} 2^{2} / 10.7$ & 18.25 & 18.27 & 0.11 & 0.869 & 0.7 & 0.8 & 14.28 & 0.468 \\
\hline & $\mathrm{M}^{3} / 5.2$ & 122.92 & 92.37 & -24.85 & 0.871 & 2381.8 & 238.54 & -1.08 & 0.009 \\
\hline & $\mathrm{M} 4^{3} / 4.8$ & 63.79 & 61.37 & -3.79 & 0.921 & 306.9 & 308.3 & 0.45 & 0.435 \\
\hline \multirow{4}{*}{$\begin{array}{l}\text { EBS } \\
1985 \\
(1247.2)\end{array}$} & $\mathrm{M} 1 / 6.2$ & 65.23 & 56.42 & -13.50 & 0.814 & 46.4 & 45.5 & -1.94 & 0.680 \\
\hline & $\mathrm{M} 2 / 10.7$ & 60.74 & 62.95 & 3.64 & 0.084 & 124.4 & 125.1 & 0.56 & 0.148 \\
\hline & $\mathrm{M} 3 / 5.2$ & 467.93 & 360.22 & -23.02 & 0.772 & 22902.6 & 22972.6 & 0.30 & 0.446 \\
\hline & M4/4.8 & 417.84 & 341.82 & -24.65 & 0.877 & 22273.1 & 22281.5 & 0.04 & 0.332 \\
\hline \multirow{4}{*}{$\begin{array}{l}\text { EBS } \\
1986 \\
(782.2)\end{array}$} & $\mathrm{M} 1 / 6.2$ & 28.41 & 27.99 & -1.48 & 0.706 & 563.5 & 560.4 & -0.55 & 0.436 \\
\hline & $\mathrm{M} 2 / 10.7$ & 58.21 & 57.62 & -1.01 & 0.696 & 989.6 & 1004.4 & 1.5 & 0.424 \\
\hline & $\mathrm{M} 3 / 5.2$ & 270.27 & 266.97 & -1.22 & 0.878 & 17613.9 & 17181.2 & -2.46 & 0.442 \\
\hline & M4/4.8 & 269.72 & 262.24 & -0.55 & 0.882 & 10855.7 & 10902.6 & 0.44 & 0.402 \\
\hline \multirow{3}{*}{$\begin{array}{l}\text { EBSJC } \\
2002 \\
(467.1)\end{array}$} & $\mathrm{M} 1^{4} / 1.8$ & 78.94 & 78.84 & -0.13 & 0.700 & 92.10 & 92.20 & 0.11 & 0.492 \\
\hline & $\mathrm{M} 2^{4} / 1.6$ & 5.11 & 5.22 & 2.15 & 0.720 & 5.10 & 5.20 & 1.96 & 0.473 \\
\hline & $\mathrm{M}^{4} / 16.3$ & 1.50 & 1.51 & 0.67 & 0.486 & 18.50 & 18.60 & 0.54 & 0.312 \\
\hline \multirow{3}{*}{$\begin{array}{l}\text { EBSJC } \\
2003 \\
(157.8)\end{array}$} & $\mathrm{M} 1 / 1.8$ & 3.75 & 1.12 & -70.13 & 0.778 & 0.70 & 0.80 & 14.29 & 0.778 \\
\hline & $\mathrm{M} 2 / 1.6$ & 2.94 & 0.77 & -73.81 & 0.695 & 0.50 & 0.50 & 0.00 & 0.695 \\
\hline & M3/16.3 & 1.48 & 0.86 & -41.89 & 0.971 & 2.40 & 2.40 & 0.00 & 0.971 \\
\hline
\end{tabular}

(1) Based on Engelund \& Hansen's method (1967); P = precipitation; Qo, Qs, Syo, Sys = observed and simulated laminas and sediment yields; Runoff error $=100\left(\mathrm{Q}_{\mathrm{s}}-\mathrm{Q}_{\mathrm{o}}\right) / \mathrm{Q}_{\mathrm{o}}$; Sediment yield error $=100\left(\mathrm{~S}_{\mathrm{ys}}-\mathrm{S}_{\mathrm{yo}}\right) / \mathrm{S}_{\mathrm{yo}} ; \mathrm{R}^{2}=$ coefficient of determination; (2) vegetated; (3) bare soil (7\% slope); (4) dead vegetation ( $8 \%$ slope).

Table 3 Error in sediment transport simulations.

\begin{tabular}{|c|c|c|c|c|c|}
\hline $\begin{array}{l}\text { Basin } \\
\text { Year } \\
\text { P (mm) }\end{array}$ & $\begin{array}{l}\text { Site/Area } \\
\left(10^{-3} \mathrm{~km}^{2}\right)\end{array}$ & Laursen & Yalin & DuBoys & Bagnold \\
\hline \multirow{4}{*}{$\begin{array}{l}\text { EBS } \\
1984 \\
(546.8)\end{array}$} & $\mathrm{M}^{2} / 6.2$ & -31.58 & 2.63 & 2.63 & 2.63 \\
\hline & $\mathrm{M} 2^{2} / 10.7$ & 14.29 & 14.29 & 14.29 & 14.29 \\
\hline & $\mathrm{M} 3^{3} / 5.2$ & -1.08 & -1.08 & -1.08 & -6.39 \\
\hline & $\mathrm{M} 4^{3} / 4.8$ & 0.46 & 0.46 & 0.46 & 0.46 \\
\hline \multirow{4}{*}{$\begin{array}{l}\text { EBS } \\
1985 \\
(1247.2)\end{array}$} & $\mathrm{M} 1 / 6.2$ & -5.17 & -0.22 & -2.37 & -0.22 \\
\hline & $\mathrm{M} 2 / 10.7$ & -1.69 & 3.78 & 3.78 & 2.73 \\
\hline & M3/5.2 & 1.05 & 2.28 & 2.71 & -22.32 \\
\hline & $\mathrm{M} 4 / 4.8$ & 14.22 & 7.39 & 8.58 & -18.95 \\
\hline \multirow{4}{*}{$\begin{array}{l}\text { EBS } \\
1986 \\
(782.2)\end{array}$} & $\mathrm{M} 1 / 6.2$ & -5.57 & 0.99 & 0.98 & -1.33 \\
\hline & $\mathrm{M} 2 / 10.7$ & -1.84 & 1.92 & 1.86 & 0.04 \\
\hline & M3/5.2 & 0.23 & 0.34 & 0.34 & 0.23 \\
\hline & $\mathrm{M} 4 / 4.8$ & 1.69 & 1.79 & 1.79 & -3.69 \\
\hline \multirow{3}{*}{$\begin{array}{l}\text { EBSJC } \\
2002 \\
(467.1)\end{array}$} & $\mathrm{M}^{4} / 1.8$ & -5.32 & 1.41 & 0.43 & 0.65 \\
\hline & $\mathrm{M} 2^{4} / 1.6$ & -72.55 & 11.76 & -1.96 & 11.76 \\
\hline & $\mathrm{M}^{4} / 16.3$ & -49.19 & 0.54 & 0.00 & 0.54 \\
\hline \multirow{3}{*}{$\begin{array}{l}\text { EBSJC } \\
2003 \\
(157.8)\end{array}$} & $\mathrm{M} 1 / 1.8$ & 28.57 & 28.57 & 28.57 & 28.57 \\
\hline & $\mathrm{M} 2 / 1.6$ & 0.00 & 0.00 & 0.00 & 0.00 \\
\hline & M3/16.3 & 0.00 & 0.00 & 0.00 & 0.00 \\
\hline
\end{tabular}

\section{CONCLUSIONS}

It can be concluded from this study that: (a) the MOSEE model was capable of representing the observed runoffs and sediment yields at micro-basins in the Cariri region of Paraíba, Brazil, under 
different annual rainfall and land uses; (b) the mechanisms of excess of flow shear and stream power in the equations of transport capacity investigated are rational to represent the sediment transport in the Cariri climate; (c) Bagnold's method, which is based on the stream power mechanism, is suggested as appropriate for the study region since it accounts for bed and suspended loads and led to slightly better results.

Acknowledgements Authors acknowledge the support of CAPES/Brazil (Coordenação de Aperfeiçoamento de Pessoal de Nível Superior) and CNPQ/Brazil (Conselho Nacional de Desenvolvimento Científico e Tecnológico).

\section{REFERENCES}

Bagnold, R. A. (1966) An approach to the sediment transport problem from general physics. US Geol. Survey, Proc. Paper 442.1, Washington.

DuBoys, M .P. (1879) Etudes du regime et L'action exerceé par les eaux sur um litá fond de graviers. Idefiniment Affouilable. Annales du Points et Chaussés, Ser. 5, 18, 141-195.

Engelund, F. \& Hansen, E. (1967) A Monograph on Sediment Transport in Alluvial Streams. Teknisk Vorlag, Denmark.

Ewen, J., Parkin, G. \& O'Connell, P. E. (2000) SHETRAN: Distributed river basin flow and transport modeling system. J. Hydrol. Engng., ASCE 5(3), 250-258.

Figueiredo, E. E. \& Bathurst, J. C. (2005). Relationship between simulated sediment yield and scale in a semiarid region of Brazil. In: Sediment Budgets 2 (ed. by A.J. Horowitz \& D.E.Walling), 110-118. IAHS Publ. 292. IAHS, Wallingford, UK.

Figueiredo, E. E. \& Davi, H. H. R. C. (2006) A model for soil erosion prediction at small scales. In: Sediment Dynamics and the Hydromorphology of Fluvial Systems (ed. by J.S. Rowan), 556-563. IAHS Publ. 306. IAHS, Wallingford, UK.

Figueiredo, E. E. \& Bathurst, J. C. (2006) Effects of rainfall variability and land-use change on sediment yield simulated by SHETRAN. In: Sediment Dynamics and the Hydromorphology of Fluvial Systems (ed. by J.S. Rowan), 620-626. IAHS Publ. 306. IAHS, Wallingford, UK.

Figueiredo, E. F. (2008). Sediment yield modelling at micro-basins and basin scales in semiarid regions of Brazil. In: Sediment Dynamics in Changing Environments (ed. by J. Schmidt et al.) 157-166. IAHS Publ. 325. IAHS, Wallingford, UK

Figueiredo, E. F \& Parsons, A. J. (2010) Incorporating pedotransfer functions into the MOSEE model to simulate runoff and soil erosion. In: Sediment Dynamics for a Changing Future (ed. by K. Banasik et al.), 353-360. IAHS Publ. 337. IAHS, Wallingford, UK.

FINEP (2004). Implantaçao de bacias experimentais no semi-árido. Projeto FINEP/FUNPEC 22010453. UFRN/UFC/UFPB/ UFCG/UFPE/UFRPE/UFBA (in Portuguese), Federal University of Campina Grande, PB, Brazil.

Graf, W. H. (1984) Hydraulics of Sediment Transport. Water Resources Publications, Highlands Ranch, Colorado, USA.

Julien, P.Y \& Simons, D. B (1985) Sediment transport capacity of overland flow. Transactions of the ASAE 28(3), 755-762.

Kirpich, Z. P. (1940) Time of concentration of small agricultural watershed. ASCE Civil Engineering 10(6).

Lopes, V. L. (1987) A numerical model of watershed and sediment yield. PhD Thesis, University of Arizona, USA.

Lopes, W. T. A. (2003) Efeitos de escala na modelagem hidrossedimentológica na região semi-árida da Paraíba. MSc Dissertation (in Portuguese), Federal University of Campina Grande, PB, Brazil.

Laursen, E. M. (1958) The total sediment load of streams. J. Hydraul. Div. ASCE 54, 1-36.

McCuen, R. H. (1982) A Guide to Hydrologic Analysis Using SCS Methods. Prentice-Hall, Inc. Englewood Cliffs, New Jersey, USA.

Souto, C. C. R A (2013) Modelagem hidrossedimentológica em bacias semiáridas com diferentes fórmulas de transporte acopladas ao modelo MOSEE. (in Portuguese), Federal University of Campina Grande, PB, Brazil.

Vanoni, V. A.(1977) Sedimentation Engineering. ASCE, American Society of Civil Engineers. New York, NY. 743 p.

Vieira, Z. C. (2011). Modelagem do escoamento e erosão sob diferentes condições de chuva e uso do solo em bacias do Cariri Paraibano com o modelo distribuído MOSEE. MSc Dissertation (in Portuguese), Federal University of Campina Grande, PB, Brazil.

Woolhiser, D. A., Smith, R. E. \& Goodrich, D. C. (1990) KINEROS: A kinematic runoff and erosion model: documentation and user manual. US Department of Agriculture, Agricultural Research Service ARS-77, $130 \mathrm{p}$.

Yalin, M. S. (1963) An expression for bedload transportation. J. Hydraul. Div. Proc. ASCE 89(HY3), 221-250. 